\title{
Växjö som miljö och fond för inre skeenden hos Pär Lagerkvist, Johannes Anyuru och Nike Krantz
}

\author{
Magnus Eriksson
}

I förordet till 2019 års upplaga av Pär Lagerkvists roman Gäst hos verkligheten, ursprungligen utgiven 1925, beskriver Ola Larsmo Lagerkvists position mellan det gamla bondesamhället och det frambrytande "modärna" (i linje med författarens idéer om ljudenlig stavning) i dessa ord:

Allt fast och beständigt förflyktigas. Människorna lossnar ur de gamla sammanhangen och befinner sig plötsligt på ett växande avstånd från de sätt att leva som format deras föräldrar, farföräldrar och generationer före dem. Anders mor och far lever i en gammaldags kristendom, men den tycks inte längre ge dem den trygghet han ännu ser hos sin morfar. Han talar om friheten i tomheten, men lugn blir han inte. Livet måste ändå uppfinnas på nytt.

Det gamla bonde-Sverige sjunker undan. Framför Anders: folkhemsbygget, nazismen, andra världskriget, Förintelsen, Stalins välde och kalla kriget, atombomben, efterkrigstidens välstånd. Det vet han inget om. Men romaner som "Gäst hos verkligheten" blir den tunna spång som förbinder allt det gamla med detta nya modärna. Den kommer att följas av fler romaner, som bygger vidare på samma bro mellan gammalt och nytt, tills genren för en tid nästan blir normen för hur svenska nittonhundratalsromaner skulle se ut. Berättelsen om det murkna gamla och omogna nya. Men få andra har klarat av det på knappt hundratjugo sidor. (Larsmo 2019: 10f)

Larsmo alluderar på den amerikanska marxisten Marshall Bermans bok Allt som är fast förflyktigas (All That Is Solid Melts Into Air, 1982). Bermans titel syftar på Marx idé i Det kommunistiska manifestet om borgarklassen som historiens dittills mest progressiva samhällsklass, därtill den enda klass som burit sitt eget avskaffande inom ramen för sitt framåtsträvande och sin kritiska självförståelse. Kanske ter det sig lätt paradoxalt att relatera orden till gammalkristen, kronobergsk bondemiljö, men Lagerkvist präglades just av den distans till uppväxtmiljö och föregående generationer som Ola Larsmo lyfter fram. Eller kanske vore det riktigare att säga att Anders, huvudpersonen i Gäst hos verkligheten och enligt gängse uppfattning i forskningen det närmaste ett alter ego för författaren vi kan komma utan att romanen blir öppet självbiografisk, formas av dessa bilder (Eriksson 2015: 123-134).

Anders står främmande både för det förflutna och det han möter i sin samtid. Miljön är trygg, både längs järnvägen västerut och promenadstråket från stationsbostaden ner mot Domkyrkan och Växjösjön. Men människorna 
är främlingar för Anders. I Gäst hos verkligheten gestaltar Lagerkvist både de sociala förändringar knutna till moderniteten som Ola Larsmo berör och ett existentiellt främlingskap hos huvudpersonen.

Anders upplever genom hela romanen ett diffust hot, inte minst genom att döden gör sitt inträde $\mathrm{i}$ hans liv och medvetande. Samtidigt förlorar han tryggheten i hemmet och i familjens starka förankring i en gammalkyrklig, luthersk tradition. Redan $i$ romanens inledning ser vi hur Anders uppmärksamhet riktas mot något annat, mot något som ingen $i$ hans omgivning ser utan som blott han förnimmer. Vi ser det tydligt i skildringen av hur Anders inte deltar i syskonens lek:

Men den minste, som hette Anders, var inte med, och det gjorde inte heller så mycket, för han kunde iallafall inte springa så fort som de andra än. Han stod kvar och tittade förundrad på förödelsen nere vid serveringen, där om kvällen allting varit så obeskrivligt vackert. $\mathrm{Nu}$ var det som ingenting, bara nersmutsat och öde. Han kunde inte fatta det. Han hade trott att det var riktigt sant alltsammans. Himlen och stjärnorna, de strålande ljusen, musikanterna som var som änglar, och musiken som ljöd så ljuvlig att man inte vågade höra riktigt efter ibland. Och nu - ingenting fanns kvar, inget kunde kännas igen. Hur kunde något sådant försvinna och bli bara tomt och ödsligt efteråt. (Lagerkvist 2019: 23f)

Lagerkvist beskriver Anders upplevelser i termer av tomhet och ödslighet. Något har gått förlorat, kvar är ett statiskt "ingenting" där det tidigare funnits liv, rörelse och munter musik.

Stillheten och tystnaden är tydliga komponenter i känslan av förlust och i förnimmelsen av något hotfullt. Den får ännu en accent när Anders kliver upp $\mathrm{i}$ ishuset. Han har just tittat på sommarhimlen, på "sommarmoln som inte flyttade sig" (Lagerkvist 2019: 34). I övrigt ser han "ingenting, bara luft, och uppe i den såg det alldeles tomt ut, som det gör ibland" (Lagerkvist 2019: 34f). Det är som om tomheten och stillheten förbereder Anders på nästa upplevelse, kylan $\mathrm{i}$ ishuset:

Där inne var det beckmörkt. Han trevade sig fram i den våta sågspånen, rysande i hela kroppen av kölden. Isflaken låg inte jämnt, på en del ställen hade det tagits mer och där var gropar, på andra tornade det upp sig. I kanterna stack isen fram bar och gjorde fingrarna stela.

Upphetsad kröp han kring där inne, kände hur kallt, hur mörkt, hur förfärligt det var. Hjärtat bankade - nej, han frös inte, det slog vid tinningarna som om han haft feber. Det var förskräckligt. Man var som begraven, visste inte om levande eller död. Man darrade av skräck ... (Lagerkvist 2019: 35)

Lagerkvist tematiserar socialt och existentiellt främlingskap, men i den långsamma uppladdningen för gestaltningen av Anders främlingskap blir det yttre rummet ett korrelat för den inre upplevelsen. Och detta yttre rum får samma stelnade karaktär som himlen i Lagerkvists tidiga lyrik. Det givna exemplet är naturligtvis inledningsdikten i Angest, 1916: 


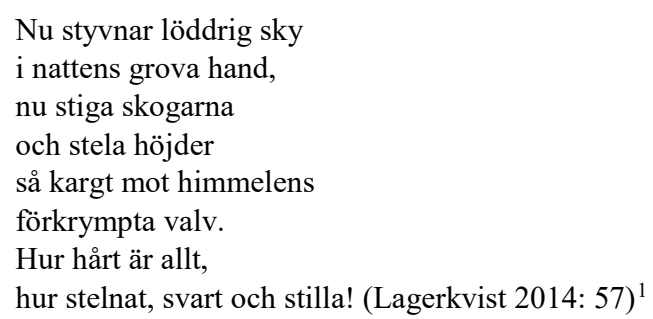

Dubbelheten av omgivande yttervärld och de fysiska förnimmelserna av kylan, tystnaden och stillheten ger en bild av Anders tilltagande upplevelse, samtidigt som den laddar upp texten med förnimmelser av hot och att en avgörande förändring kommer att ske. Och vad som sker är att Anders blir medveten om döden. Det skeendet knyts till mormodern, som får kräftan och avlider. Men innan dess ger Lagerkvist flera bilder av hur Anders gradvis närmar sig medvetenheten och samtidigt fjärmar sig från de människor som påminner honom om döden. Det börjar med hans och faderns besök hos Anders morföräldrar en bit västerut längs järnvägen. Anders far är järnvägstjänsteman och de tar trallan för att besöka de gamla. Anders känner väl igen allt som finns hos morföräldrarna. Han är hemma där, men det är också som om något annat öppnas: "Någon vind märktes inte, lönnarna stod och sov uppe i solen, till och med aspen, som annars är ett rörligt träd, stod still en bit bakom honom vid södra gaveln" (Lagerkvist 2019: 46f). Det kunde varit en stillsam idyll - om det inte vore för aspen. Att den står stilla understryker hotet.

Sedan präglas hela besöket av Anders tilltagande olust. Lagerkvist ger flera bilder av stillaståendet, av det murkna, av lukten av ålderdom. På ett fysiskt sätt blir Anders medveten om att morföräldrarna skall dö. Och i förlängningen att de alla skall dö, även han själv. Men Anders har en tillflykt i skogen, en sten där han ber. Där får han utlopp för en tro på trots mot hemmets trygga och förtröstansfulla tro. Hans bön är ivrigare och intensivare än de böner han hör i hemmet; kanske blir han hörd när han ber om en enda sak:

Att han inte skulle dö, att ingen av dem skulle dö, säkert ingen! Att far skulle leva, mor, syskonen - räknade upp dem - de gamla ute på landet, alla, alla! Att säkert ingen skulle dö! Att det skulle vara så som det var. Att ingenting skulle ändras. (Lagerkvist 2019: 60)

Att ingenting skulle ändras. Men allt är förändrat. Molnen står stilla på sommarhimlen, tomheten, kylan, den orörliga aspen. Och mormor dör. Hon är själv tillfreds inför döden, trygg i sin tro. Men för Anders blir mormoderns död den slutliga bekräftelsen på trons otillräcklighet. Scenerna från

1 Den symboliska framställningen av själen som ett förkrympt himlavalv eller som människor nedtryckta mot jorden av detta präglar åtskilliga dikter både i Motiv, 1914 och Ångest, 1916. 
mormoderns begravning har fått egen klassikerstatus. Där fullföljer också Lagerkvist kontrasten mellan det förstelnade och rörelsen, mellan tystnaden och ljuden, en motsättning som riskerar att överbryggas av mörkret.

Anders iakttar begravningshögtiden och den efterföljande middagen. Han ser överdådet $\mathrm{i}$ denna. Bygdens kvinnor bidrar alla till en mångfald av maträtter och ostar. Som traditionen föreskriver ska alla smaka på allt, men Anders drar sig för tårtan. Den ser visserligen god ut, men han stöts bort av det svarta korset som den dekorerats med. Han drar sig undan stojet. Han går ut på gården: "Nere på gaveln var ett fönster som syntes märkvärdigt stilla, alldeles som om ingen funnits där inne" (Lagerkvist 2019: 90). Där ser Anders hur hans morfar sitter upprätt i sängen där hans mormor dött:

Den gamle satt orörlig. Ovanpå pratade de och skrek, han fäste sig inte vid det och hörde det kanske inte. Läste med den höga röst som han alltid haft, den tandlösa munnen rörde sig. Anders kunde väl höra vart ord.

Äntligen slog han igen bibeln och knäppte händerna över den.

- Amen, i Guds den Allsmäktiges namn. Amen. Men när han lagt boken på stolen bredvid sängen såg han ut i rummet och talade om igen.

- Herren din Gud skall uppväcka dig på den yttersta dagen.

Sedan lade han sig ner och blåste ut ljuset, och mörkret liksom bara uppslukade honom. (Lagerkvist 2019: 91)

Begravningsmiddagen inger Anders en känsla av trygghet, kanske en paradoxal känsla. Det är liv och rörelse. Men tryggheten är illusorisk. Det är inte Anders liv, inte hans rörelse. Han är en främling inför det livet. Men hans främlingskap gäller också den religiositet som hans morfar visar. Där råder stillhet. Och allt övergår i mörker.

Kapitlet slutar med att Anders ser sin morfar uppslukas av mörkret. I det följande kapitlet möter vi Anders längre fram i livet. Barnet har trätt in i ungdomen. Han promenerar i staden och längs landsvägarna. Han flyr hemmet: "Det låg något beklämmande $\mathrm{i}$ all denna bundenhet, all tyngden $\mathrm{i}$ hemmet" (Lagerkvist 2019: 92).

Uppbrottet är ångestfyllt. Ser vi Anders ångest både inför hemmet och den tillvaro som möter honom utanför detta, liksom hans grubblerier över ungdomens förbannelse, i sitt litterära tidssammanhang kastar symbolismens fin de siècle-stämning och Hjalmar Söderbergs avklarnat känslomättade flanörprosa sina skuggor över Lagerkvists bild av den unge Anders.

Även här är Anders på en gång fångad i och lockad av två skilda förhållningssätt, men utan att kunna förankra sin egen existensförståelse i något av dem. Han är dessutom sjuk: "Han skulle dö av den bröstsjukdom som han nu fătt" (Lagerkvist 2019: 95). Hemmet ger ingen tröst, trots hans mors omsorger. Det är alltför präglat av en kristen förtröstan som är honom främmande; han visar en närmast aggressiv attityd mot denna. I stället vänder han sig till en ateistisk åskådning: 
Nej, den nya läran som man fick i sig, den som sopade bort Gud och all förhoppning, som lade livet öppet och rått, i hela dess nakenhet, hela dess planmässiga meningslöshet, den hjälpte bättre, den ville en väl. (Lagerkvist 2019: 96f)

Ångestupplevelsen och de religiösa funderingarna balanseras dock av, och finner kanske sin kontrast i, Anders vandringar i skogen med en gammal kamrat, Jonas. För Anders har inte naturen någon högre mening, det var inte därför han i barndomen bad till stenen, men han trivs med Jonas som på sitt sätt personifierar naturmänniskan och ett oskuldsfullare tillstånd. Lagerkvist skildrar inkännande hur de snärjer gäddor, och det är uppenbart att det finns något hos Jonas som lockar Anders. Men det är inte hans liv, varken naturen eller en urbanare ungdomstillvaro. Än en gång hamnar han mellan de skilda inställningarna till livet.

Romanen slutar i ännu ett laddat möte för Anders. Mest av en händelse hamnar han på Norrgatan, som fortfarande hör till "de norra kvarteren, nästan i utkanten" (Lagerkvist 2019: 105). Han lockas av sången som han hör på en bakgård och av ljusen i ett fönster. Därinne håller Frälsningsarmén möte. Anders rycks till en början med i de innerliga och extatiska stämningarna. Utlevelsen speglar en annan religiös attityd än den som härskar i hemmet. ${ }^{2}$ Han intas också av en ung kvinna som vittnar om sin tro, om hur Gud lyft henne ur synden:

Hon blev frimodigare. Ibland lyfte hon blicken, såg ut i salen. Men mumlet av bönerna runtomkring hetsade inte upp henne, när de suckade och stönade fick hon bara någonting varmare i rösten. Det var något så rent och fattigt över henne där hon stod i sin mörkblå kappa av mörkblå cheviot. Den var sliten. På somliga ställen var den alldeles blank, mest på vänstra sidan, där hon brukade bära tidningspacken när hon var ute och sålde Ropet. Men det slitna var vackert här i lampskenet. Det liksom lyste i tyget. Det passade henne. Anders tyckte åtminstone så. Han tog aldrig ögonen från henne, från ansiktet, som då hon talade blev barare, som om man såg henne först nu. Den bleka munnen tycktes le när hon öppnade den. Men det var inte ett leende utan bara något vekt och gott hos själva läpparna. Det bara var så. (Lagerkvist 2019: 110f)

Det är en ypperlig skildring av en förälskad yngling. Men är Anders förälskad i den unga frälsningssoldaten? Lagerkvist ger en tvetydig bild. $\AA$ ena sidan tycks Anders förtrollad - kanske förvandlad, å andra sidan blir atmosfären under mötet allt outhärdligare för honom. Efter mötet är hans känsla otvetydig: "Vad han kände var äckel. Fullkomlig leda. Och en isande kyla i sitt inre, en hätskhet mot allt som kunde vilja komma inpå honom ..." (Lagerkvist 2019: 113).

Återigen kylan, återigen drar sig Anders undan.

2 I dikten "På Frälsningsarmén" i Ångest (Samlade dikter, sid 73) ger Lagerkvist en starkt inkännande bild av ett möte hos Frälsningsarmén, en bild som aldrig får den komplikation som Anders möte med organisationen. 
En stund efter mötet träffar han den unga kvinnan igen. De promenerar ner mot sjön. Anders frågar om hon tror på Gud. Hon berättar okonstlat, uppriktigt och innerligt om sin tro. Den är fylld av förtröstan. Trots de extatiska stämningar som tidigare under kvällen fångat Anders, påminner kanske hennes tro alltför mycket om familjens?

En stund tittar Anders "som om han älskade henne" (Lagerkvist 2019: 115). Han ser hennes renhet. Men "dragen blektes, som om de inte var jordiska - men utan att förandligas i extas, i upphetsad lidelse, hänryckning. De var bara stilla" (Lagerkvist 2019: 115).

Återigen stillheten. Anders känner sig beklämd av den unga kvinnan. Han förfäras av fullkomligheten, av trosvissheten, av friden. Anders förblir den utanförstående. Han kan inte älska kvinnan som han intagits och förbländats av. Han kan inte ens förstå henne. Och han blir inte ett med vare sig naturen eller staden. Han följer kvinnan hem:

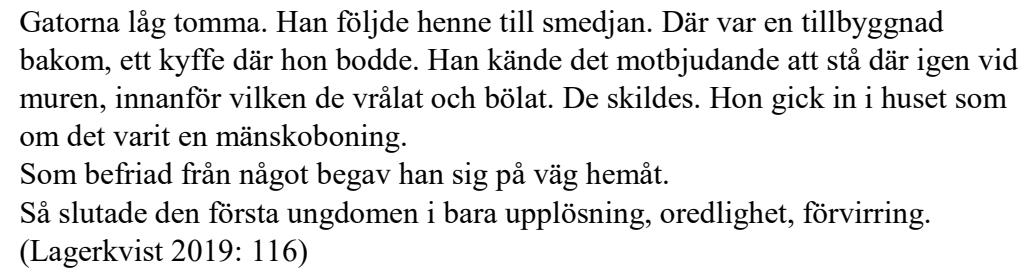

Det är romanens sista ord. Den slutar i tvetydighet. Anders är kanske befriad, men till vad? Han har brutit upp, men han lever också i en förlust. Men en förlust av vad? Hans längtan är en längtan bort från de tidigare livs- och familjesammanhangen, men det slutar i "upplösning, oredlighet, förvirring."

Gäst hos verkligheten är en bildningsroman. Den brukar också tolkas som en roman med självbiografiska inslag; jag går inte längre än till ordet "inslag" för att inte fastna i avgrunden mellan den biografiska fakticitetsfrågan och en textteoretisk diskussion om skriftens distansering och avskurenhet från textens primära kontext - eller författarens situation, förståelse och avsikt.

Att Gäst hos verkligheten är en bildningsroman är ett rimligt antagande, trots att slutorden handlar om förvirring och upplösning. Det är en genrebestämning, en idé som endast söker sitt stöd i ett genrehistoriskt sammanhang. Men så har vi frågan om det är en Växjöroman. Det antagandet baseras på författarkontextuella omständigheter. Pär Lagerkvists far tjänstgjorde vid järnvägen i Växjö. Flera släktingar bodde i Öja, nära Gemla mellan Växjö och Alvesta.

Romanen ger ytterligare signaler om Växjö. Sjön i staden, alltså Växjösjön, ligger i centrum. Norrgatan är en faktisk gata, där Frälsningsarmén hade sin lokal vid den tid då handlingen utspelas. Norrgatan är dock det enda 
namnet i romanen som kan förankras i Växjö. Dessutom finns en gata med det namnet i många svenska städer, och Växjö är inte den enda staden som har en sjö i centrum.

En läsare som känner Växjö läser dock utan svårigheter in de topografiska detaljer som romanen ger i den konkreta staden, eller i staden som den såg ut i början av 1900-talet. Sjön i staden blir Växjösjön, järnvägsresan med trallan går västerut mot Öja, familjens tjänstebostad låg i samma byggnad som järnvägsrestaurangen.

Men det är också slående att Lagerkvist är så sparsam med namn som kunde göra miljön konkretare. Kanske ska vi inte se Gäst hos verkligheten som en roman om Växjö? Genom att namn och detaljer reducerats blir tematiken överordnad miljön. Pär Lagerkvist skriver en roman om existentiellt främlingskap och uppvaknande. Som Larsmo påpekar ger han också en bild av brytningen mellan tradition och framväxande modernitet $\mathrm{i}$ den tidens Sverige. Lagerkvist tecknar en miljö som vilken läsare som helst, eller åtminstone många, kan se som en bekant miljö, kanske en egen livsmiljö. Läsaren från Växjö ser sin egen stad, men den som lever i en annan, mindre stad kanske ser denna, eller i alla fall något som kunde vara en igenkännbar verklighet.

Jag tror att namngivning förankrar den litterära texten i en konkret miljö, men att sparsamhet med namn - och framför allt utelämnande av namn på byn, staden eller landskapet - öppnar för en generellare syftning, en mer läsarorienterad än författarinriktad identifikation med den frammanade världen.

När Johannes Anyuru år 2003 debuterade med diktsamlingen Det är bara gudarna som är nya, behandlades boken som en symbolisk framställning av sociala motsättningar, men också av kärlek i ett samtida Sverige befolkat av gudar och heroer från de homeriska eposen. Läsningarna var lyhörda, och det finns inga skäl att kritisera kritikerna för bristande känslighet - inte heller för att de missade att några namn kunde hämtats från Växjös lokalgeografi.

När jag själv läste boken samma år, kort efter utgivningen, studsade jag till inför dessa ord tidigt i boken: "i rondellen rinner bilarna bort uppför / Liedbergsgatan och tar eld, det är i januari” (Anyuru 2003: 25). Raderna skärpte min uppmärksamhet för miljön, inte bara de tematiska mönstren. Något senare dyker de här verserna upp:

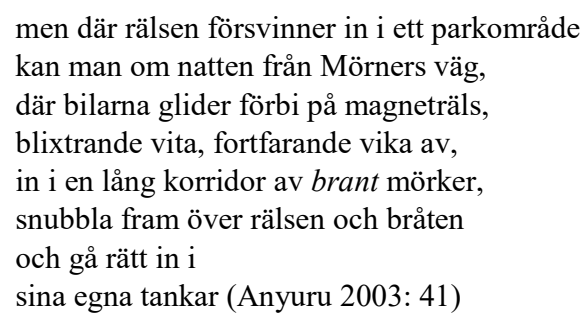


Raderna ger inte bara en fin, nattlig bild, de ger också en stark bild av nattrafiken på Mörners väg i Växjö som på ett drabbande sätt vävs samman med en vinddriven vandrares upplevelse.

Johannes Anyuru förankrar dikten i en konkret miljö, i Växjö. Ett par rader om "Dalbo Vårdcentral" (Anyuru 2003: 51) återkallar, åtminstone för mig, T S Eliots rader om Starnbergersee i början av "Det öde landet" och allusionen på Babels floder senare i dikten. (Eliot 1963: 63, 70; Eliot 1987, 32, 38) Liedbergsgatan återkommer senare i boken (Anyuru 2003: 77).

Men Anyurus debutbok är inte en diktsamling om Växjö, och den rymmer inte dikter med Växjömotiv. De lokalgeografiska namnen förankrar skeendet i en pågående svensk verklighet. De ger ram och sammanhang för dikterna, inte en konkret referens. Det viktiga är att skapa en scen för de sociala motsättningar, strider och existentiella upplevelser som lyriken tematiserar. För den som identifierar namnen, och som kanske känner igen sig som nattlig vandrare längs Mörners väg sedan diskoteket Barbarella på Västra industriområdet stängt (nu är vi nere i sjuttiotalet), innebär inte namnen att texten begränsas. Den behåller sin tematik, men miljön antar konkret gestalt.

Johannes Anyuru växte delvis upp i Växjö, Nike Krantz kommer från Växjö. Det nämns på fliktexten till hennes debutroman Klara livet, 2020. Där nämns också att romanen utspelas i Växjö. Men inte heller Nike Krantz nämner staden vid namn. Hon skriver i jag-form. Vi möter en ung kvinna som går sista året på gymnasiet, och vi får följa henne genom en alltmer traumatisk kärlekshistoria. Vandringarna i staden och stundom halsbrytande cykelfärder, inte minst från en stadsdel som inte namnges men vars läge sammanfaller med Teleborg, har en viktig roll i romanen. Men även här bildar staden mer en fond för skeendet än en miljö i egen rätt.

Det understryks, liksom hos Lagerkvist och Anyuru, av den sparsamma namngivningen. Av de tre klassiska konditorierna i Växjös centrum besöks två, Skåres och Askelyckan. Att inte Broqvist får vara med beror troligen på att de unga flickorna söker avskildhet i kafémiljöerna; sådan ges inte där.

Jag tror att de tre författarna förenas av en idé. De ger inte i första hand bilden av en stad, utan av en livsmiljö. De skapar en grund för läsarens identifikation med spelplatsen de upprättar med namn och miljöbeskrivningar, men vad läsaren ser är inte i första hand en konkret, i texten identifierbar stad, utan sin egen. Böckerna handlar inte om författarnas stad, utan om läsarens hemvist. Det är den som manas fram i medvetandet hos läsaren när hen ser den litterärt gestaltade miljön. För läsare som känner Växjö kan sedan författarens stad och den egna hemvisten sammanfalla, men bara delvis. Ålder, personliga erfarenheter, sociala omständigheter, tiden då det utspelas: sådant skiljer sig alltid åt och skapar distans mellan författaren och läsaren. En ung läsare i Växjö får knappast samma förnimmelser av den nattliga vandringen längs Mörners väg som en äldre. Jag utgår också från att min lätt druckna ungdomsassociation från sjuttiotalet inte heller fanns i Anyurus föreställningsvärld. 
Men det delvisa sammanfallet kan också skapa en komisk effekt i mötet med en kritiker som hemfaller åt en förenklat social läsning, eller ideologisk låsning:

\section{Referenser}

Anyuru, Johannes (2003), Det är bara gudarna som är nya, Stockholm: Wahlström \& Widstrand.

Bergquist, Lars (1978), Spegelskrift, Stockholm: Norstedts.

Ehriander, Helene (2009), "Att göra de osynliga synliga: Solveig OlssonHultgrens Smålandssvit", Speglingar av Småland, red:er Inger Littberger Caisou-Rosseau, Maria Nilson och Carina Sjöholm, s. sid 185-196, Hestra: Isaberg förlag.

Eliot, T S (1963), Collected Poems 1909-1962, London: faber and faber.

Eliot, T S (1987), Dikter i svensk tolkning, översättning Karin Boye och Erik Mesterton, Stockholm: Bonniers Delfin.

Eriksson, Magnus (2015), "Bilder av staden", Pendulum Kalmar-Växjö, Linnéuniversitetet: Linnæus University Press, s. 123-134.

Krantz, Nike (2020), Klara livet, Stockholm: Förlaget Knappen.

Lagerkvist, Pär (2019), Gäst hos verkligheten, Stockholm: Brombergs.

Lagerkvist, Pär (2014), Samlade dikter, Stockholm: Brombergs.

Larsmo, Ola (2019), förord till Pär Lagerkvist: Gäst hos verkligheten, Stockholm: Brombergs.

Lundberg, Johan, (2003), recension av Johannes Anyuru: Det är bara gudarna som är nya, Svenska Dagbladet, 3 april, 2003. 